\title{
Unveiling the Experience of Volunteers and Beneficiaries: A Case of AGAK Foundation, Inc
}

\author{
Jabin J. Deguma*, Melona C. Deguma, Regina E. Sitoy, Emerson D. Peteros, Limuel J. Abelgas, \\ Irene O. Mamites, Mary Anne C. Villaganas, Porferio M. Almerino Jr., Ann Frances P. Cabigon, \\ Floro D. Marturillas, Honorio C. Añora, Dennis B. Plando, Helen O. Revalde, Jemima N. Tandag, \\ Venus Z. Loremia, Harlene Marie B. Acebes, Ricardo Q. Ybañez, Danilo F. Cebe, Teresita T. Rojas, \\ Reylan G. Capuno
}

College of Education, Cebu Technological University, Cebu City, Philippines

Email address:

jabindeguma@gmail.com (J. J. Deguma)

*Corresponding author

\section{To cite this article:}

Jabin J. Deguma, Melona C. Deguma, Regina E. Sitoy, Emerson D. Peteros, Limuel J. Abelgas, Irene O. Mamites, Mary Anne C. Villaganas, Porferio M. Almerino Jr., Ann Frances P. Cabigon, Floro D. Marturillas, Honorio C. Añora, Dennis B. Plando, Helen O. Revalde, Jemima N. Tandag, Venus Z. Loremia, Harlene Marie B. Acebes, Ricardo Q. Ybañez, Danilo F. Cebe, Teresita T. Rojas, Reylan G. Capuno. Unveiling the Experience of Volunteers and Beneficiaries: A Case of AGAK Foundation, Inc. International Journal of Education, Culture and Society. Vol. 5, No. 1, 2020, pp. 10-19. doi: 10.11648/j.ijecs.20200501.12

Received: March 10, 2020; Accepted: March 25, 2020; Published: April 7, 2020

\begin{abstract}
Community-academe partnership is a pragmatic effort to promote social responsibility by implementing sustainable development goals set by the United Nations Development Programme. On the one hand, a religious community-based organization like the Archdiocesan Shrine of San Roque Parish provides not only spiritual nourishment but also delivers socio-economic sustainability programs for impoverished members. On the other hand, an academic community like Cebu Technological University as a higher learning institution participates in nation-building by knowledge and resources sharing through community extension service. This paper assessed through unveiling the multi-faceted experiences of volunteers and beneficiaries of AGAK Foundation, Inc., using a qualitative descriptive research design. Exploration and understanding of the experiences of stakeholders generate a holistic picture of how the community dynamically behaves overtime. The study expedited the identification and assessment of the community's needs, which is a salient procedure in crafting a community extension service in the case of higher learning institutions in the Philippines. The result exposed emerging themes: a.) the genesis of AGAK Foundation, Inc.; b.) the various services it offered; c.) the pressing concerns of the adult-beneficiaries; and d.) the prevailing challenges encountered by the organization. Discussion of the themes furthered the need to address the different yet interrelated sustainable development goals by proposing an appropriate community extension service thereafter.
\end{abstract}

Keywords: Sustainable Development Goals, Community Needs-assessment, Community Extension Service, Higher Learning Institution, Qualitative Research

\section{Introduction}

The prime means to help the marginalized and vulnerable members of society cope with the perennial problem of poverty is to provide them with an opportunity for decent and sustainable work or livelihood. The Archdiocesan Shrine of San Roque Parish (ASSRP) of Barangay Mambaling, Cebu City, finds such as a primordial concern. Situated in a poor urban community with a population of almost 30,000 people,
ASSRP understood that its task is not only to provide spiritual nourishment but also to render socio-economic sustainability. ASSRP cannot ignore the plight of minors, ranging from five to fifteen years old, who comes from a family of more than five members, whose parents are jobless and roam around the alleys and streets. Not having the means to enjoy a decent home, these minors opt to spend most of their time on the streets and experience life on the other side of the fence, thereby exposing them to all kinds of menace and extreme 
hazards. Confronted with an enormous scale of poverty and hopelessness, ASSRP launched AGAK FOUNDATION, Inc. intending to sustain the program, which involves gathering these kids every evening at the parish to attend mass and tutorial classes and catechesis in an attempt to educate them, despite the transition of priests.

Recent studies showed that interagency collaborative effort can solve socio-economic related problem of communities [4, 32, 50]. Educational sectors and private corporations performed community outreach programs to impoverished communities, especially in urban settings [27, 24, 37]. In the Philippines, higher learning institution commits to helping the country achieve sustainable development goals (SDG) as envisioned by the United Nations Development Programme. Previous researchers highlighted the effort of the country's educational sector alongside the challenges it encountered to achieve the different yet interrelated SDGs. The studies of David et al. [11] and Deguma et al., [13] found out that the quality of gender equality correlates with the quality of peace and justice of the country. The study of Ocampo et al. [43] fostered awareness on the importance of emphasizing SGDs on clean water sanitation, sustainable cities and communities, and life below water in policy-making on the area of ecotourism of the country. Roldan [46] accentuated the holistic understanding of the interrelatedness of SDGs like no poverty, zero hunger, quality education, and decent work, and economic growth. Henceforth, Roldan [46] added that the academe, as a vital stakeholder, can back the attainment of SDG through community partnership and adaptation of a localized program.

Indeed, the academe and community partnership is a pragmatic effort to implement sustainable development goals by instilling the value of social responsibility to their respective constituents. Higher learning institutions in the Philippines are mandated to perform their tri-fold functions (Instruction, Research, and Extension Service). These tri-fold functions are crucial means to carry out the four Pillars of Education by UNESCO (learning to be, learning to know, learning to do, and learning to live together). Whereby, areas on Instruction and Research equipped both faculties and students of proper resources and expertise. These resources and expertise are shared and dispensed to underserved and depressed communities through Extension Service and strong community linkages or partnerships [9]. Higher learning institutions can participate in nation-building through knowledge sharing and capacitation work [46].

More so, an exploration of needs may contribute to the emergence of issues and trends vital to the implementation an extension service by higher learning institutions [2, 3], and [18]. Needs-assessment uncovers the situations needed for possible extension services [29]. Several studies supported the importance of community needs-assessment before crafting an appropriate extension service [20, 35, 36, 53, 39].

Hence, this study assessed the current experiences of the volunteers and beneficiaries of the AGAK Foundation, Inc., and how their social status behaved through individual and collective accomplishments in social change. The Cebu
Technological University (CTU), as one of the largest state-sponsored higher learning institutions in the Philippines, has to address the need by connecting to and assessing its surrounding communities. The study would also provide new insights regarding issues and concerns that affect the well-being of people in the community. This study geared to come up with a proposed community extension service that will capacitate the adult beneficiaries through skills training development, which is rooted in their present conditions, and provide technical assistance to the AGAK Foundation, Inc. to fulfill its mission continuously.

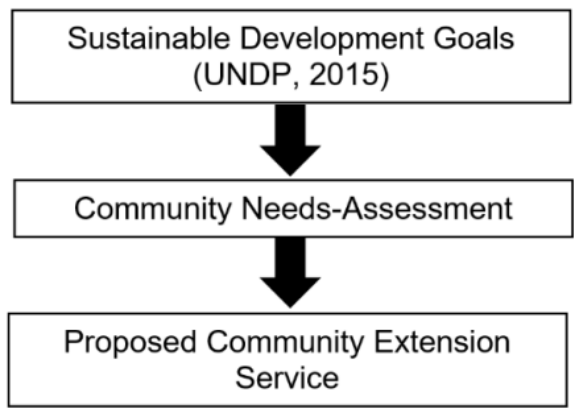

Figure 1. Conceptual Framework of the Study.

\section{Methods}

\subsection{Research Design}

The study utilized qualitative descriptive research design. According to Nardi [40] and Latifah [31], the method provided a detail presentation of the lived experiences of the individual respondents. Also, it extracts significant responses from the key informants to capture emerging themes. Focus Group Discussion (FGD) of key informants collects in-depth information. It sorts ideas that are salient in the lives and experiences of the respondents could be generated [22, 25, 7]. Unlike phenomenology, grounded theory, and ethnography, which maintains a theoretical standpoint, this study captured qualitative descriptions and points of view of the key informants regarding their lived-experiences in the periphery of AGAK Foundation, Inc.

\subsection{Participants and Procedure}

The study was conducted in ASSRP where no manipulation of the environment was done. The researchers asked the assistance of the parish priest. It utilized purposive non-probability sampling from key informants who can provide insightful answers. Key informants of the study included volunteers $(\mathrm{N}=10)$ and adult-beneficiaries $(\mathrm{N}=14)$. They were asked to share their experiences in four separate FGD sessions. It is further qualified that they are regular attendees of the activities initiated by AGAK Foundation, Inc. for the past four years since its establishment. Utilizing the local dialect of the key informants, which is Sinugbuanong Binisaya as the medium used in the interview process, could generate genuine and authentic responses [23, 10]. The key informants were informed on the confidentiality concerns, 
especially on the utilization of the voice recorder, which helps the researchers in transcribing and analyzing the data from the interviews. The researchers prepared questions that directed the structured interviews with the key informants. The questions were raised using Sinugbuanong Binisaya to make it understandable for the key informants who could not comprehend well in English. The sessions started by asking the demographic profile of the key informants like age, gender, civil status, and educational attainment. Moreover, the researchers also prepared two separate lists of questions for volunteers and adult-beneficiaries.

The researchers analyzed the answers of the key informants by coding the different concepts generated from the transcription. In this manner, the gathering of accurate ideas is facilitated. Coding is a necessary procedure in qualitative research that is systematically organizing and sorting of raw data. In the process, coding takes through different forms, including open coding, axial coding, and selective coding. By repeating this coding process, the researchers identified different substantial themes among responses. Various themes were generated patterns from transcriptions supported by the verbatim accounts of the key informants.
Guide questions for the volunteers:

V-Q1. Nganong mi-apil man ka isip volunteer sa AGAK? [Why did you join as volunteer of AGAK?]

$V$-Q2. Unsa ang mga pagtulon-an nga nakuha nimo sa pag-apil sa AGAK? [What lessons have you learned from participating in AGAK?]

$V$-Q3. Unsa ang mga kalisdanan nga imong naagian isip volunteer sa AGAK? [What are difficulties you have experienced as volunteer of AGAK?]

V-Q4. Unsa ang kinahanglan nga palamboon sa AGAK? [What does AGAK need to develop?]

Guide questions for the adult-beneficiaries:

$A B-Q 1$. Unsa ang imong panginabuhian? [What is your livelihood?]

AB-Q2. Unsa ang mga kabalaka nga imong naagian karon? [What concerns you right now?]

AB-Q3. Unsa ang mga natabang sa AGAK sa imoha? [What are benefits you received from AGAK?]

AB-Q4. Unsa ang gusto nimong ma-improve o mapalambo pa sa imong panginabuhian? [What do you want to improve in your livelihood?]

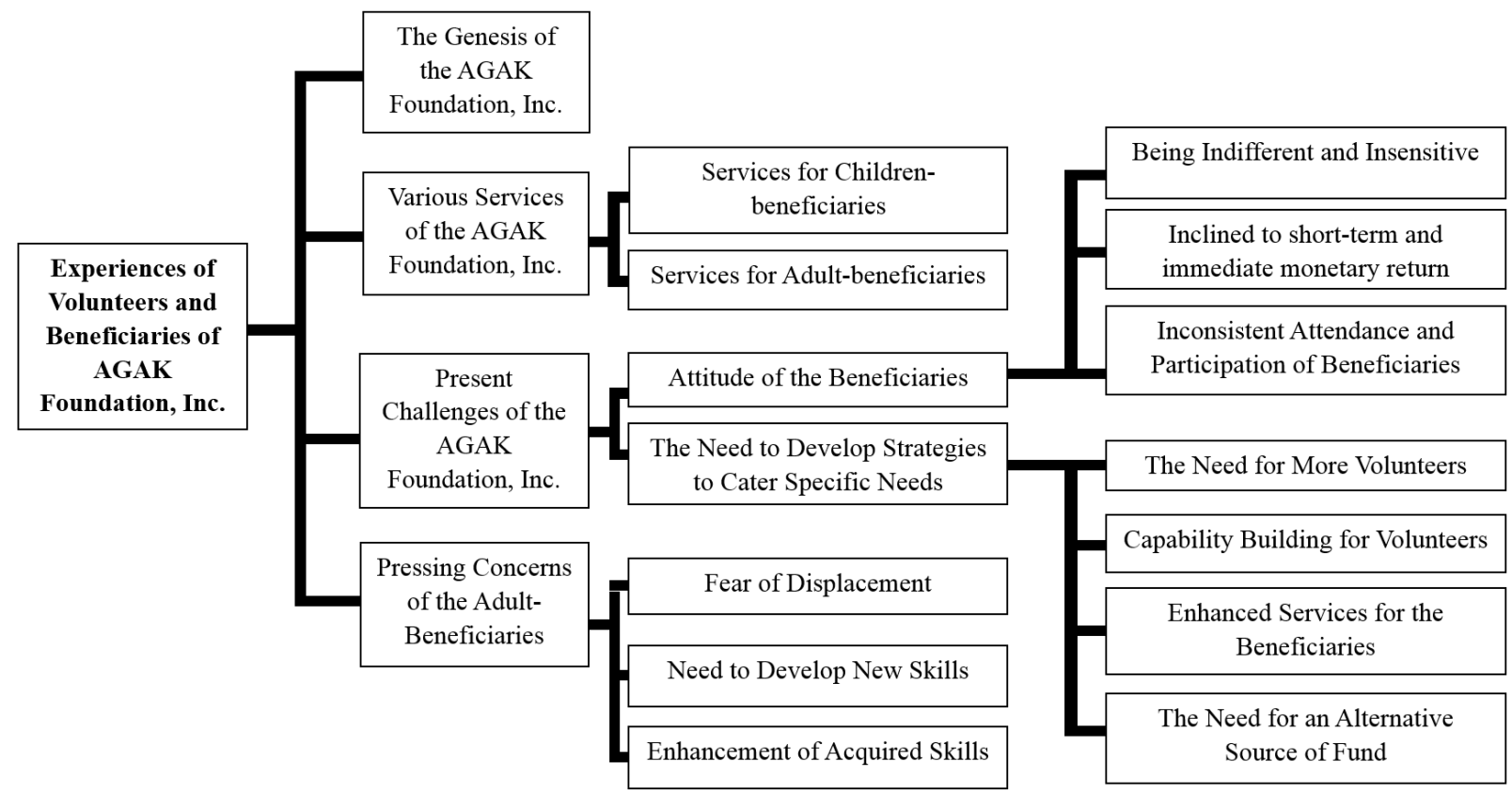

Figure 2. The Thematic Outline of the Experience of Volunteers and Beneficiaries of AGAK Foundation, Inc.

\section{Results and Discussion}

\subsection{The Genesis of the AGAK Foundation, Inc}

Confronted with an enormous scale of poverty and hopelessness, ASSRP launched a program known as AGAK "Atong Gugma Alang sa Kabataan" (Our Love for Children) to cater to the needs of street children. As recounted by a volunteer:

V3: "ang start up jud sa AGAK... kang Fr. Sarmago pa ni last 2016, around January, it's the new Paschal Theme... how to (respond) in the year of Mercy, mao to naka come up mi sa among PPC meeting, kaning mga street children nga makahibalo sila nga naay simbahan, ug welcome diay sila sa simbahan" [It all started as an initiative of Father Sarmago last 2016 to respond to the Catholic Church's Year of Mercy... the parish pastoral council convened a meeting that focused on helping children so that these children will realize that there is a church that cares for them].

This humble beginning as a parish initiative has transformed into an avenue for social empowerment. The response of ASSRP as a "work of mercy" underwent a metamorphosis. From being a simple response, ASSRP advanced into creating a recognized charitable movement, whose intention is to sustain the program despite the transition of the priest. On August 18, 2018, AGAK Foundation, Inc. 
was formally recognized by the Securities and Exchange Commission (SEC) as a non-stock corporation. Non-stock corporations may be formed or organized for charitable, religious, educational, professional, cultural, fraternal, literary, scientific, social, civic service, or similar purposes, like trade, industry, agricultural and like chambers, or any combination thereof, subject to the special provisions of this Title governing particular classes of non-stock corporations (B. P. 68., Art XI, Sec. 88). At its present phase, AGAK Foundation, Inc. of ASSP runs its daily operation for its beneficiaries, including children and adults. It has a total of more than ten (10) volunteers who selflessly helped in providing the different services. The foundation catered more than sixty (60) children-beneficiaries and thirty (30) adult-beneficiaries.

\subsection{Various Services of the AGAK Foundation, Inc}

AGAK Foundation, Inc. promotes the integral human development of the people who are poor and marginalized, especially the urban poor, to alleviate their cause through training, education, and formation programs. Purposefully, the foundation provides services explicitly for the following beneficiaries:

\section{(i). Children-Beneficiaries}

The program involves gathering of kids every evening at the parish to attend mass and tutorial classes and catechesis in an attempt to educate them. These children are also treated to daily dinner at the church so that a regular feeding program accommodated the basic needs of food. As recounted by volunteers:

V1: "naa mi daily activities sa mga bata, magsugod mi alas singko sa hapon... magrosaryo ang mga bata, unya magprepare mi ug snacks" [The volunteers prepared daily activities for children, we will start at five in the afternoon, the children will join us in praying the rosary, then they will be served with snacks].

V6:"Moproceed na dayon ni sila sa simbahan kay paatenon ni sila ug misa sa alas says, magtutorial mi human sa misa human unya manihapon ni sila una manguli" [The children will attend holy mass at six in the evening where they served as the church choir, then the tutorial session will follow for an hour, and before letting the children go home, they will be served with dinner].

Every night from Monday to Friday, the volunteers will prepare varied activities such as tutorial and catechism, bible sharing, skills building, sports and recreation, and watching movies. Another religious organization, the Oasis of Love, will also provide a recollection for these children every first Sunday of the month. The volunteers have noticed that the children-beneficiaries were able to acquire desirable actions. As revealed by the volunteers, noticeable improvements are observed:

V3: "nagpasalamat mi nga kamao na sila magpray like angelus" [We are thankful that they already learn how to pray].

V4: "natagaan sila ug opportunidad nga madisiplina" [They are provided with an opportunity to learn the value of discipline].

V2: "nakabantay ko nga sauna mag-iyahay ni sila, hinayhinay nakalearn sila sa value of unity" [I observed the changes in their behavior, before they do things individually, but now they learn the value of unity].

Child outcomes are interconnected within and across diverse domains of development. The result are enhanced by early positive and supportive interactions with parents and other caregivers. These early interactions can have a long-lasting ripple effect on development across the life course, whereby the function of one domain of development influences another domain over time. As the AGAK Foundation Inc. expands its services to its beneficiaries, starting June of 2018, it has supported ten (10) children as scholars to school with the hope that they would have a brighter future.

\section{(ii). Adult-Beneficiaries}

As an adjunct service, the Foundation also assists in giving livelihood opportunities to parents. Parents are also invited to attend every Sunday mass and undergo catechesis and formation. They are also provided with livelihood like soap making and selling mineral water so that they can stand on their own and provide a better living to their respective families. As confirmed by the adult-beneficiaries, the parish pastoral program has been their source of economic and financial "refuge," as majorly reported by the adult-beneficiaries themselves:

AB1:“Dako jud ang natabang sa AGAK sa amoa" [AGAK Foundation has been a great help for us].

AB4:"Naka-abag jud ang gihatag nga ayuda sa parokya sa akoa" [The assistance given by the parish to us was very significant].

AB8:"Natagaan jud mi ug oportunidad nga makabaton ug dugang pohonan sa among panginabuhian" [We were given with an opportunity to have an additional source of income].

The adult-beneficiaries have received help in various ways from AGAK Foundation, Inc. One form of assistance they received is through receiving an amount of money, which served as supplemental capital for their existing livelihood. Although the help they receive doesn't improve their status quo, albeit it gave them immediate sustenance to indulge in their everyday living. As reported by adult-beneficiaries:

AB5:"Bisan man ug dili makadato ang gipahulam sa amoa, makatabang-tabang jud ni sa inadlaw namong panginahanglan [We are aware that the financial assistance we received will not make us financially well, but it helped us cope with our daily expenses].

AB11: "Naa jud koy makoot para sa bawn sa akong anak" [I used the money to send my child to school].

AB13: "Gigamit nako ug sa akong bana ang kwarta para palit ug dugang materyales sa paghimo ug haplas" [My husband and I used the money to buy ingredients in making ointment].

As maintained by Kuang-Jung [30], the Philippines' informal sector is characterized by a large number of small-scale production and service activities that are 
individually or family-owned. Kuan-Jung [30] added that this is primarily due to the little formal education and lack of skills, as well as a lack of capital resources. Hence, there is a great need to resolve the small-scale mentality by empowering the community and made them skillful.

\subsection{Pressing Concerns of the Adult-beneficiaries}

The urgent concerns of the adult-beneficiaries reflected the quality of their life. The very status quo of the adult-beneficiaries reflected in their answer when asked about their present situations, which can be generalized through the following themes: fear of displacement, need to develop new skills and enhancement of acquired skills.

\section{(i). Fear of Displacement}

This theme was brought up by the respondents when they shared their most immediate concerns. As reported by the key informants, the most challenging issue which they fear now is the possibility and impending demolition and relocation. The need to equip resettlement with essential services for a decent living [34]. Not to mention water, food supply, etc., but most of all, sustainable programs of urban alleviation [5], is the real source of fear which the key informants are afraid. Despite being labeled as illegal settlers, they claim to have the right to stay. As vulnerable as they are, the limited social, physical, and financial capital have even pressed them to be more sensitive and fearful [19]. As appealed by the informants:

AB2:"ang among dakong problema jud kay kanang papahawaon na mi" [Our biggest problem right now is our impending relocation].

AB13: "layo kaayo ang relocation, wala nami panginabuhian didto" [the relocation site was very far, and we are afraid that we won't have a new source of income].

AB9: "diri nami nakamat-on ug buut, ug sakit sa amoa nga papahawaon" [We were born and live here, it hurts us thinking that we are driven away from our home].

AB10: "ok ra namo erelocate, basta tarong lang unta among kahimtang" [It is okay for me to be relocated so long as our well-being will not be compromised].

\section{(ii). Need to Develop New Skills}

Grierson et al. [21] probed that helping the marginalized members of the society acquire skills by providing the opportunity to work and a prospect of training avenues will facilitate an opening for the socio-economic participation for them. Such need was also felt by the key informants when they see the need to develop new skills, which might give them more delightful opportunities ahead of them. One crucial observation which this paper highlight is the varied skills that they relayed. As recounted by the adult-beneficiaries:

AB1: "kon tagaan mi ug higayon nga makat-on manahi ilabi na nang trapo" [if I will be given a chance to learn how to sew especially rags].

AB5:"gusto mi makahibalo anang housekeeping" [I wanted to be trained as a housekeeper].

AB8: "kanang makatrabaho ta sa hotel, manlimpyo" [I want to work in a hotel].
AB10: "nindot makahibalo anang trabaho sa sikyo" [I want to work as a security guard].

AB14:"malipay ko kon matagaan ko og chance nga makamao moluto kanang sud-an" [I will be happy if I will be trained in cooking].

Although the adult-beneficiaries are showing a definite desire to acquire new skills, it is undeniable that poverty alleviation was the primary reason to resort to skills development. Individuals living in scarcity of opportunity tend to focus on how skills development will help to solve poverty $[6,26]$. The adult-beneficiaries viewed skills development as a process that creates long-lasting solutions to alleviate poverty.

As recounted by adult-beneficiaries $(\mathrm{N}=14)$, the Majority of them agreed to be trained in rag-making particular sewing circle rags $(\mathrm{n}=10)$. The remaining are interested in other skills opportunities such as housekeeping and janitorial services $(n=2)$, foods related $(n=1)$, and security-related training $(n=1)$. When asked why most of the beneficiaries preferred the former, they reported that some of them had previously experienced selling of circle rags.

\section{(iii). Enhancement of Acquired Skills}

The adult-beneficiaries are aware of the benefits they received from the parish organization. One of which was the skills they acquired and made profitable despite low financial return. As testified by the adult-beneficiaries:

AB13: "ma-improve ang mga nasugdan namo like paghimo ug downy ug dishwashing" [We hope to improve the skills which we are trained like the making of fabric softener and liquid detergent].

AB11: "matudloan mi unsaon nga mas makahalin mi" [We wanted to learn how to earn more from the skills we got from our training].

These statements reflect the need to enhance their acquired skills. Moreover, the necessity to improve expertise is more likely to be connected to better enterprise-led approach skills training (Grierson et al., 2002). The adult-beneficiaries recognized that there is a need to develop an enterprise -led skills which may uplift and provide better financial returns. Hence, by identifying the existing economic climate, opportunities to create enterprise-led abilities could thrive in [8].

\subsection{Prevailing Challenges of the AGAK Foundation, Inc}

AGAK Foundation Inc. fought against hunger, poverty, and illiteracy to address social injustice. The volunteers strive to provide the needs of beneficiaries despite the lack of monetary rewards. In performing the different services offered by the foundation, there are emerging challenges encountered by the volunteer, which impede success and a better outcome.

\section{(i). Attitude of the Beneficiaries}

Money can alleviate the harsh conditions of poverty, but unless it is used to leverage changes in behavior, it will have a little lasting effect [47]. It is indisputable that because of the benefits which the foundation provides to the beneficiaries, 
the level of participation among beneficiaries increases. However, despite the persistent and consistent assistance, beneficiaries still exhibit attitudes that are incongruent to the help they received. Volunteers observed the following attitudinal manifestations among the beneficiaries.

a) Being Indifferent and Insensitive.

The most notable attitude of the beneficiaries is indifference and insensitiveness. Volunteers observed these attitudes, especially on their experience with the adult-beneficiaries. As claimed by the volunteers:

V4:"usahay naay mga ginikanan nga dili kamao magpasalamat" [We notice that there are parents who are not grateful].

V7: “tungod pud sa ilang naandan nga mga batasan" [They have an undesirable attitude of being indifferent].

V10:"mga batang squatter man pud gud ni sila sa una, unya karon ginikanan na, mao nang naa jud silay batasan nga dili masabtan" [These parents were once street children and have grown up as parents, because of that they acquired undesirable attitudes].

Indifference is the absence of interest, attention, or enthusiasm, not incline someone or something. Such an attitude is an outcome of the quality of the environment where a person lives. Upbringing makes a gigantic difference in making a person considerate, respectful, and thoughtful. Singh [49] purported that family that nurtures the values of being kind and selfless passes them on to posterity effortlessly. If selfishness and callousness is not checked at an early age, if some member of the family exhibits such traits, children unconsciously pick them up.

b) Inclined to short-term and immediate monetary return.

Another concern is the beneficiaries' inclination on short-term solutions and quick financial gain. As recounted by the volunteers:

V4: "gusto jud ang kasagran sa ilaha anang easy money" [Most of them want to get money without earning it].

V8: "Natrain nana sila ug dishwashing ug fabric making pero moreklamo murag gusto sila magpasayon" [They are trained to make dishwashing detergent and fabric softener yet didn't apply the skill to earn money from it].

V9: "Mao nang murag effective ning pagpahulam sa ilaha ug kwarta kay madawat man dayon nila" [The giving of monetary assistance seemed convenient for them since they can immediately get the money].

V10: "tingale tungod kay nabuhi man ni uban nila sa pagpanglimos sa dalan mao nang gusto sila ug dali nga kwarta" [Maybe because most of them lived as mendicants in the streets, that is why they don't work for money].

The experience of intergenerational poverty experience must be considered in understanding people living under below poverty line [47]. Sawhill [47] stressed that the experience of poverty has greatly influenced people's behavior and attitude. This is the reason why a more significant challenge is posed in dealing with people who are less fortunate and illiterate. It is a must, therefore, to consider this attitudinal factor in handling the beneficiaries, since their responsiveness is almost always attached to how motivated they are. That is why the alternative livelihood program of giving monetary assistance to the beneficiaries was seen to be "effective" because it fits into their need and mindset as people who live with meager resources and usually cannot think with long-term opportunities. There is no doubt that helping the poor is a pious action and even a Christian mandate. However, doing nothing about the experience intergenerational poverty is negligence of social responsibility.

c) Inconsistent attendance and Participation of Beneficiaries.

An additional attitudinal problem that was observed from the beneficiaries is the inconsistency of attendance and participation of beneficiaries. As reported by volunteers:

V2: "usahay daghan ang mo-attend, usahay gamay ra" [there are times that many would come, sometimes only a handful would participate].

V3: "nabantayan nako, kanang December, daghan kaayo motambong kay daghan man lagi mga ipanghatag" [I noticed that during December, most of them would attend our activities since there would receive many donations].

V6: "karon tungod sa mga coupon, motambong sila kay pohon naa may raffle ug ipanghatag in exchange sa ilang pag-anhi diri" [now because of the coupons, they will attend because they would join the raffle program and received an item in exchange for coming here.]

It is imperative to note that these beneficiaries are always after for rewards and reinforcement. In the study of Mikander [38], the right combination of immaterial and material rewards can boost a person's motivation and enhance their commitment to participate. This observation is significant to consider in providing beneficiaries with more opportunities and services. More so, their economic status can drive them to be motivated because of some extrinsic rewards they received. As described by a volunteer:

V5: "bisan ug mga ginagmay lang ang ilang madawat, grabi kaayo kadaghang ginikanan mo-ari, nangiyawat intawn", [even if they receive only small amounts, most parents will take it seriously].

However, despite this unbecoming behavior of the adult-beneficiaries, volunteers have also noticed some critical changes in behavior. As noted by a volunteer:

V5: "naa puy nakita namo nga kausaban, especially kadtong magcige ug join sa among mga activities" [we have seen changes, especially those who are actively participating in our activities].

V8: "sauna, maglumbaanay rajud ug kuha sa ipanghatag, karon kahibalo na sila mo linya" [we notice before, they used to be selfish just to catch for distribution, but now they learn how to wait].

Through constant participation of the beneficiaries in the activities of the foundation, they have slowly adapted desirable values that are unnoticeable before. Hence, the social interaction within the foundation promotes a change of behavior, which is a key to personal and social development according to social development theory [12]. 


\section{(ii). The Need to Develop Strategies to Cater to Specific Needs}

Another pressing challenge in which the AGAK Foundation, Inc. must deal as a charitable institution is to provide specific activities to cater to the particular needs of their beneficiaries. The foundation has maintained daily activities that sustain participation among beneficiaries (e.g., regular feeding program, scholarship, livelihood alleviation program, and giving of coupon). The tendency of dependency and mendicant mindset are more likely to be acquired by the beneficiaries rather than training them to become productive members of the society [44]. Several aspects need to improve and develop strategies to enhance the quality of services.

a) More Volunteers.

With the growing numbers of beneficiaries and the development of the services of the foundation, it is undeniable that the need for more volunteers is a possible challenge. As shared by the volunteers:

V4: "usahay makafeel mi ug kakapoy kay daghan kaayo ang mga bata, unya gamay ra mi" [sometimes we get tired because we have so many children to attend, but there are only a handful of volunteers].

V8: "Naay uban mo try ug join as volunteers, pero later tungod tingale kay naa silay laing priority maong dili kaayo sila committed" [Some tried to join as volunteers, but because they have another priority, they become less committed].

V10: "sa nagkadaghang bata ug ginikanan nga miapil na sa AGAK murag kinahanglan jud nga daghan ang mga moboluntaryo" [more and more children and parents are joining AGAK, we need more people to volunteer].

Volunteers are of enormous value to a non-profit organization [17]. Not only do volunteers help to save money, but they can provide better service to clients, increase contact with the greater community, make available better expertise, and reduce costs of services. At par with serving the beneficiaries, finding for dedicate volunteers can be a challenge as well. Hence, the foundation must make sure to develop a strategy in recruiting dedicated volunteers who can help realize the goal of the foundation. The organization must know the particular needs of the beneficiaries to determine which kind of assistance is required from a volunteer. Fritz [16], opined a way to recruit volunteers for a non-profit organization by providing a "recruitment message." This message must be a compelling one that will highlight the significance and worthiness of the help which a volunteer can give and render to the organization. Hence, it must be carefully and purposefully drafted to a prospect who can be of help to the Foundation's specific service. Organization must highlight the benefits the volunteer will receive [16].

b) Capability Building for Volunteers.

The volunteers find meaning and identify the reasons behind their decision to join as volunteers. They believed that significant reasons drive such an act of service:

i. fuelled by passion:

V4: "malipay ko nga makaserbisyo" [I would love to serve].
V7: "nindot ang pamati nga makatabang ko sa mga bata" [it feels good to be able to help the kids].

V9: "ganahan ko matudloan sila sa maayong pamatasan" [I love teaching them good manners].

ii. means to pay back:

V2: "gipaeskwela ko sa Missionary of Charity" [The Missionary of Charity sponsored my education].

V5: "pamaagi nako sa pagpasalamat sa Ginoo" [way to thank the Lord].

V6: "It's my way to give back sa parish sa pagtabang nako" [It's my way to give back to the parish when I needed help].

iii. means to develop one's personality:

V1: "makatabang nako nga maka-enhance sa akong skills kay nagskwela man ko to become a teacher pohon" [it helps me improve my skills as I study to become a teacher someday].

V3: "mas nitaas na akong pasensya karon compare sauna nga wala pako sa AGAK" [I'm more patient now compared before when I was not yet part of AGAK].

V8: "nakakita ko ug laing mga friends diri sa AGAK" [I meet new friends here in AGAK].

V10: "kanang tinuod nga friends jud" [real friends indeed].

Indeed, by joining AGAK Foundation, Inc., the volunteers were able to develop something inside them, which helps become true Christ-like disciples. Moreover, volunteers reported that by participating, they are given a chance to handle conflict and be aware of their own emotions and temper, thereby enhancing their social skills. Likewise, the volunteers are also able to build a social network among themselves. As noted by Segal \& Robinson [48], volunteerism offers vital help to people in need, worthwhile causes, and the community. Still, the benefits can be even more significant for the volunteer. Volunteerism can reduce stress, combat depression, keep you mentally stimulated, and provide a sense of purpose [48].

The volunteers still felt that there is a need to capacitate them so that they can become better and more effective service front liners. They sensed the need to advance their skills, especially in dealing with people. Skills development can help become an active volunteer. Skills that need to be developed include personal and interpersonal skills [41]. Particular skills include self-confidence, communication skills, self-awareness, self-management, planning, taking responsibility, improving own learning, problem-solving, and decision-making. Also, interpersonal skills are precise skills such as teamwork, managing relationship, active listening skills, leadership, and negotiation.

c) Enhanced Services for the Beneficiaries.

Service enhancement is an indication of a progressive program. The key to an active service enhancement is recognizing both the strengths and weaknesses of an organization. This is primarily done through constant evaluation and allowing feedback. By so doing, service enhancement is realized in designing a comprehensive program that is tailored to individual needs and concerns [33]. Hence, for the AGAK Foundation, Inc. to be more responsive and be a catalyst for positive change, it must promote 
activities that can positively make its beneficiaries productive members of the society. Therefore, as a response, there are three primary services which the foundation can enhance particularly, improved educational opportunities for children-beneficiaries, practical livelihood project for the beneficiaries, and better-quality incentive for the volunteers.

\section{d) Alternative Source of Fund.}

To continuously serve the beneficiaries, AGAK Foundation, Inc. generates monetary, goods, and services from different sources. The Foundation receives diverse donations and pledges from well-off parishioners, philanthropic individuals, and groups, which can significantly help to fulfill its herculean task. Another initiative of the Foundation was to raise funds during the Christmas season and some other special occasions that involved the parishioners (e.g., fiesta, Basic Ecclesial Community Meetings among others). As narrated by the volunteers:

V3: "gikan sa mga lain-laing taw nga gusto motabang sa foundation" [from different people who want to help the foundation].

V5: "naa mi Light a Belen every December" [The parish has an activity every December we called it 'Light a Belen'].

V9: "makapangayo mi ug donations gikan sa nagkalainlaing chapels" [we asked for donations from various chapels in the parish].

Moreover, the foundation also connects with industries that can help them provide livelihood programs for the adult-beneficiaries. Such acts of generosity have undoubtedly helped sustain the foundation. Nevertheless, the parish priest and the volunteers still felt the need to adapt actions that can help withstand as a self-sustaining charitable organization. As related by the volunteers:

V2: "mas mayo jud nga naay income ang foundation nga dili magsalig sa mga hinabang sa mga benefactors" [it would be sustainable for the foundation to generate an income and no longer rely on the assistance of benefactors].

V8: "nindot unta nga maka come up ang foundation ug livelihood project para sa mga ginikanan, ug at the same time, maka-in come pud ang AGAK nga maoy gamiton pohon sa mga activities" [it would be suitable for the foundation to come up with a livelihood project for the parents and, at the same time, could generate income from it].

It is in this context that the Foundation's aim to be self-sufficient can venture into social enterprising. In so doing, the Foundation will no longer be dependent on donations by generating more of its income through the livelihood program it offers to its beneficiaries. A social enterprise, according Defourney \& Nyssens [14] and Alter [1], is an innovative response to the funding problems of non-profit organizations. The principal aim of social enterprise is to serve the community to promote a sense of social responsibility at the local level $[14,42]$. As an innovative approach to becoming a social enterprise, the foundation can address the social needs of the beneficiaries, which is to have a sustainable livelihood [45]. Hence, providing a livelihood for the adult-beneficiaries can be more realized by transforming the foundation into a social enterprise.

\section{Conclusion}

This paper recognizes the effort of the ASSRP program AGAK Foundation, Inc. in providing opportunities for the beneficiaries to survive from the harsh environment of economic and financial survival. The creation of AGAK Foundation, Inc. is a tangible enactment of the Catholic Church's social teaching, specifically the preferential option for the poor through ASSRP. In a statement given by Pope John Paul II to the Workers of Ecuador [15], the pope claimed that the problem of ordinary injustice and the exploitation of work has long been a concern of the Catholic Church... as an integral part of her mission, she can and must always proclaim her moral, human, and Christian principles and values of social life. One may argue that these social issues are first and foremost under the purview of sociology, politics, and economics. The Catholic Church, being the Mother and Teacher of people identify with the suffering and the hardships of all men, especially the poor.

Moreover, the needs of the beneficiaries can be considered as systemic. On the one hand, their fear of being displaced and be relocated in a less socio-economic locale is anchored on their collective assertion of rights to live as a community which existence precedes the claim of the legally rightful owner over the lot area. While on the other hand, their clamor to acquire new skills and enhance the previously acquired ones is pleas for a decent living, which could alleviate their collective experience of poverty.

Lastly, the needs of the beneficiaries can be collectively perceived as the need for the foundation itself. By helping the organization grow and become sustainable could provide a holistic solution that improves the life and wellbeing of its members, the beneficiaries themselves.

Proposed Extension Program. Cebu Technological University, through the faculty of the College of Education, Main Campus, continues to commit in fulfilling its mission and in extending its services through expanded community engagement and building human capital through skills enhancement training to the prospect beneficiaries. The results of the needs assessment are the basis for a community extension. The faculty of the College of Education proposes a skill training on circle rag-making (trapo) for sustainable livelihood to the adult-beneficiaries. It would also help the AGAK Foundation, Inc. become a social enterprise by generating a viable source of a fund through becoming a quality supplier of rags as finished products produced by its adult-beneficiaries.

\section{References}

[1] Alter, K. (2007). Social enterprise typology. Virtue Ventures $L L C, 12,1-124$.

[2] Arnold, M. E. (2015). Connecting the dots: Improving Extension program planning with program umbrella models. Journal of Human Sciences and Extension, 3 (2), 48-67.

[3] Arnold, M. E., \& Cater, M. (2016). Program Theory and Quality Matter: Changing the Course of Extension Program Evaluation. Journal of Extension, 54 (1), n1. 
[4] Bartels, K. P. (2018). Collaborative dynamics in street level work: Working in and with communities to improve relationships and reduce deprivation. Environment and Planning C: Politics and Space, 36 (7), 1319-1337.

[5] Berner, E. (1996). Legalizing squatters, excluding the poorest: Urban land transfer programs in the Philippines.

[6] Bruton, G. D. \& Ketchen Jr, D. J. (2013). "Entrepreneurship as a solution to poverty," Journal of Business Venturing, vol. 28, pp. 683-689.

[7] Compare, A., Tasca, G. A., Lo Coco, G., \& Kivlighan Jr, D. M. (2016). Congruence of group therapist and group member alliance judgments in emotionally focused group therapy for binge eating disorder. Psychotherapy, 53 (2), 163.

[8] Dann, L., Ware, N., \& Cass, K. (2009). Tackling exclusion in the creative industries: an enterprise-led approach.

[9] Daquis, M. A., Flores, N. A., \& Plandez, R. Z. (2016). Implementation of extension project of the radiologic technology department in one Barangay of San Jose, Batangas, Philippines. Asia Pacific Journal of Education, Arts, and Sciences, 3 (3), 109-115.

[10] Dash, N. S., \& Ramamoorthy, L. (2019). Corpus and Dialect Study. In Utility and Application of Language Corpora (pp. 139-153). Springer, Singapore.

[11] David, C. C., Albert, J. R. G., \& Vizmanos, J. F. V. (2018). Sustainable Development Goal 5: How Does the Philippines Fare on Gender Equality?

[12] David, L. (2014). Social Development Theory (Vygotsky) in Learning Theories. Retrieved from https://www.learning-theories.com/vygotskys-social-learningtheory.html.

[13] Deguma, J. J., Peteros, E. D., Case, M. S., \& Igot, V. J. (2018). Violence against Women and Gender Equality in the Philippines: Are They Related?. Journal of Educational and Human Resource Development, 6, 68-81.

[14] Defourny, J., \& Nyssens, M. (2006). Defining social enterprise. Social enterprise: At the crossroads of market, public policies and civil society, 7, 3-27.

[15] De Torre, J. M. (1997). Politics and the Church: From Rerum Novarum to Liberation Theology $2^{\text {nd }}$ Edition. Manila: UA\&P.

[16] Fritz, J. (2019). 3 Ways to Recruit Volunteers for Your Nonprofit. Retrieved from https://www.thebalancesmb.com/recruit-volunteers-for-your-n onprofit-2502581.

[17] Fundraising Consulting. (2014). Volunteers: What Can They Do For You Today? Retrieved from https://cdsfunds.com/volunteers_what_can_they_do_for_you.

[18] Gagnon, R. J., Franz, N. K., Garst, B. A., \& Bumpus, M. F. (2015). Factors impacting program delivery: The importance of implementation research in Extension. Journal of Human Sciences and Extension, 3 (2), 68.

[19] Gaillard, J. C. (2009). From marginality to further marginalization: Experiences from the victims of the July 2000 Payatas trash slide in the Philippines. Jàmbá: Journal of Disaster Risk Studies, 2 (3), 197-215.

[20] Garcia, R. C., \& Paguia, D. (2018). Socio-Economic Need Assessment of a Rural Area in the Philippines. Available at

\section{SSRN 3303031.}

[21] Grierson, J., Schnurr, J., \& Young, C. (2002). Reaching marginalized people: Linking skills training and the world of work. Technical and Vocational Education and Training in the 21st Century: New Roles and Challenges for.

[22] Gołuńska, D., Kacprzyk, J., \& Herrera-Viedma, E. (2015). Modeling different advising attitudes in a consensus focused process of group decision making. In Intelligent Systems' 2014 (pp. 279-288). Springer, Cham.

[23] Haryono, A. (2018). Communicative Competence in Mlayokaken Tradition of Banyuwangi 'Using'Community. The International Journal of Social Sciences and Humanities Invention, 5, 4923-4930.

[24] Heald, M. (2018). The social responsibilities of business: Company and community, 1900-1960. Routledge.

[25] Howell, A. J., Jacobson, R. M., \& Larsen, D. J. (2015). Enhanced psychological health among chronic pain clients engaged in hope-focused group counseling. The Counseling Psychologist, 43 (4), 586-613.

[26] Hussain, M. D., Bhuiyan, A. B., \& Bakar, R. (2014). Entrepreneurship development and poverty alleviation: An empirical review. Journal of Asian scientific research, 4 (10), 558.

[27] Jabeen, S., Ul Haq, M. N., \& Hussain, I. (2018). Community Participation in Socio-Economic Development through Secondary Education in one of the Remotest Regions of Pakistan. European Online Journal of Natural and Social Sciences, 7 (4), pp-663.

[28] Karlan, D., Ratan, A. L., \& Zinman, J. (2014). Savings by and for the poor: a research review and agenda. The Review of income and wealth, 60 (1), 36-78.

[29] Krumwiede, K. A., Van Gelderen, S. A., \& Krumwiede, N. K. (2015). Academic - hospital partnership: Conducting a community health needs assessment as a service-learning project. Public Health Nursing, 32 (4), 359-367.

[30] Kuang-Jung, C. (1997). The sari-sari store: informal retailing in the Philippines. Journal of Small Business Management, 35 (4), 88.

[31] Latifah, H. N. (2019). The Challenges faced by Volunteers in "Desa Bahasa dan Wisata Tayuban" (Doctoral dissertation, Universitas Muhammadiyah Yogyakarta).

[32] Lee, D., McGuire, M., \& Kim, J. H. (2018). Collaboration, strategic plans, and government performance: the case of efforts to reduce homelessness. Public Management Review, 20 (3), 360-376.

[33] Lewallen, T. C., Hunt, H., Potts - Datema, W., Zaza, S., \& Giles, W. (2015). The Whole School, Whole Community, Whole Child model: a new approach for improving educational attainment and healthy development for students. Journal of School Health, 85 (11), 729-739.

[34] Lim, A. M., Jordan, C. M., \& Tangente, M. G. C. (2013). Policy audit: Social protection policies and urban poor LBTs in the Philippines (No. Evidence Report; 21). Institute of Development Studies (IDS).

[35] Llenares, I. I., \& Deocaris, C. C. (2018). Measuring the Impact of an Academe Community Extension Program in the Philippines. Malaysian Journal of Learning and Instruction, 15 (1), 35-55. 
[36] Medina, M. A. P. (2018). A Community Extension Framework for Philippine Higher Education Institutions: A Model Developed from Small-Scale Climate Change Adaptation Projects of Central Mindanao University. World Scientific News, 105, 204-211.

[37] Medina, M. A., Grim, J., Cosby, G., \& Brodnax, R. (2020). The Power of Community School Councils in Urban Schools. Peabody Journal of Education, 1-17.

[38] Mikander, C. (2010). The impact of a reward system on employee motivation in Motonet-Espoo. Retrieved from https://www.theseus.fi/bitstream/handle/10024/16956/carolina mikander.pdf?

[39] Mores, L. S., Lee, J., \& Bae, W. (2019). University-Community Partnerships: A Local Planning Co-Production Study on Calabarzon, Philippines. Sustainability, 11 (7), 1850.

[40] Nardi, P. M. (2018). Doing survey research: A guide to quantitative methods. Routledge.

[41] National Youth Agency. (2007). Young People's Volunteering and Skills Development. Retrieved from https://dera.ioe.ac.uk/6643/1/RW103.pdf.

[42] Pennel, C. L., McLeroy, K. R., Burdine, J. N., \& Matarrita-Cascante, D. (2015). Nonprofit hospitals' approach to community health needs assessment. American journal of public health, 105 (3), e103-e11.

[43] Ocampo, L., Ebisa, J. A., Ombe, J., \& Escoto, M. G. (2018). Sustainable ecotourism indicators with fuzzy Delphi methodA Philippine perspective. Ecological indicators, 93, 874-888.

[44] Orbeta, A. C., \& Paqueo, V. B. (2016). Pantawid Pamilya Pilipino Program: Boon or Bane? (No. 2016-56). PIDS Discussion Paper Series.
[45] Ridley-Duff, R., \& Bull, M. (2015). Understanding social enterprise: Theory and practice. Sage.

[46] Roldan, M. D. G. Z. (2018). Towards Attaining the Sustainable Development Goals: The Philippines and the 2030 Agenda. In DLSU Research Congress 2018.

[47] Sawhill, I. V. (2003). The Behavioral Aspects of Poverty. Retrieved from https://www.brookings.edu/articles/the-behavioral-aspects-ofpoverty/.

[48] Segal, J. \& Robinson, L. (2018). Volunteering and Its Surprise Benefits. Retrieved from https://www.helpguide.org/articles/healthy-living/volunteering -and-its-surprising-benefits.htm/.

[49] Singh, B. (2015). Emotional Shadows. Retrieved from https://balroop2013.wordpress.com/2015/09/21/why-are-peopl e-so-insensitive/.

[50] Susha, I., \& Gil-Garcia, J. R. (2019, January). A collaborative governance approach to partnerships addressing public problems with private data. In Proceedings of the 52nd Hawaii International Conference on System Sciences.

[51] Tabuga, A. D., \& Reyes, C. M. (2012). Conditional cash transfer program in the Philippines: is it reaching the extremely poor? (No. 2012-42). PIDS Discussion Paper Series.

[52] Wenocur, S., \& Reisch, M. (2001). From charity to enterprise: The development of American social work in a market economy. University of Illinois Press.

[53] Wynne, A. L., Nieves, P. M., Vulava, V. M., Qirko, H. N., \& Callahan, T. J. (2018). A community-based approach to solid waste management for riverine and coastal resource sustainability in the Philippines. Ocean \& Coastal Management, 151, 36-44. 